\title{
Policy Recommendations for Industrial Green Development in the Tianshan Mountain Northern Slope Economic Belt
}

\author{
Xie Minghui ${ }^{1,2}$, Meng Lihong ${ }^{1,2}$, Li Xueying ${ }^{1,2}$, Bai Lu $^{1,2}$, Bai Weinan $^{3}$, Qiao Qi ${ }^{1,2}$ \\ 1. State Key Laboratory of Environmental Criteria and Risk Assessment, Chinese Research Academy of Environmental Sciences, Beijing 100012, China \\ 2. Key Laboratory of Eco-Industry of the Ministry of Environmental Protection, Chinese Research Academy of Environmental Sciences, Beijing \\ 100012, China \\ 3. State Key Joint Laboratory of Environment Simulation and Pollution Control, School of Environment, Tsinghua University, Beijing 100084, China
}

\begin{abstract}
The Tianshan Mountain Northern Slope Economic Belt is the largest economic belt in China, and is a development focus under the Belt and Road Initiative. Green development in this economic belt provides an important reference for other countries along the Belt and Road route. This study assesses the environmental performances of the Tianshan Mountain Northern Slope Economic Belt based on regional and industrial levels. Three wings of this economic belt - the south wing, the middle wing, and the north wingare defined using the results of the environmental performance assessment. The environmental performance of the north wing (which includes the Kuytun, Karamay, and Wusu economic zones) is the best, followed by that of the south wing (which includes the Gulja, Korgas, and Qapqel economic zones, the Urumqi and Changji economic zones, and the Turpan and Kumul economic zones). The environmental performance of the middle wing (which includes the Shihezi, Manas, and Shawan economic zones and the Bortala, Jinghe, and Alashankou economic zones) ranks lowest. Strategies for the green industrial development of these three wings are suggested based on the assessment results.
\end{abstract}

Keywords: Tianshan Mountain Northern Slope Economic Belt; environmental performance assessment; green industrial development; policy suggestion; industry

\section{Introduction}

In 2013, when President Xi Jinping visited Central Asian and Southeast Asian countries, he proposed the Belt and Road Initiative. The Tianshan Mountain Northern Slope Economic Belt is a comprehensive economic belt that has been given priority for the development of the Belt \& Road Initiative of China. Its green development shall be pivotal to the sustainability of the Belt and Road Initiative.

At present, the study of the Tianshan Mountain Northern Slope Economic Belt has begun in the field of economic development [1-3], and has been gradually followed by environmental issues, mainly issues like ecological quality [4,5], environmental carrying capacity $[6,7]$, and urbanization $[8,9]$. The research on green development focuses on the industries such as food industry [10], construction industry [11], automobile industry [12], mineral industry [13], energy industry [14,15], and so on However, studies on the green development of the Tianshan Mountain Northern Slope Economic Belt are few. Therefore, this study will evaluate the environmental performance of each economic zone from the perspectives of region and industry and propose a green development strategy for regional industries, with a view to suggesting steps for the policy support to the green development of the industries in the economic belt.

Received date: June 26, 2017; Revised date: July 12, 2017

Corresponding author: Xie Minghui, Ministry Environmental Protection Key Laboratory of Eco-Industry, Chinese Research Academy of Environmental Sciences, Associate Professor. Major research field is technology and policy of green development. E-mail: huibird82@163.com

Funding program: CAE Advisory Project "Strategies for Ecological Civilization Construction of the Tianshan Mountain Northern Slope Economic Belt in Xinjiang" (2015-ZD-16); “Strategies for Cleaner Production Technology in Key Industries in China during the New Period” (2014-XZ-18).

Chinese version: Strategic Study of CAE 2017, 19 (4): 079-087

Cited item: Xie Minghui et al. Policy Recommendations for Industrial Green Development in the Tianshan Mountain Northern Slope Economic Belt. Strategic Study of CAE, https://doi.org/10.15302/J-SSCAE-2017.04.013 


\section{Overview of region areas}

The Tianshan Mountain Northern Slope Economic Belt is located in the middle of the north slope of Tianshan Mountain, to the southern margin of the Junggar Basin, Xinjiang, with Urumqi, Shihezi and Karamay as its axes. According to the Xinjiang Statistical Yearbook 2015, the total output value of the Tianshan Mountain Northern Slope Economic Belt in 2014 was 638.69 billion Yuan, accounting for $68.9 \%$ of the gross output value (927.346 billion Yuan) of Xinjiang Uygur Autonomous Region (hereinafter referred to as Xinjiang). The total output values of the primary, secondary, and tertiary industries in the Tianshan Mountain Northern Slope Economic Belt were 63.299, 293.849, and 281.542 billion Yuan respectively, making up $41.1 \%, 74.4 \%$, and $74.4 \%$ respectively [16], of the output values of Xinjiang, as shown in Fig. 1.

The 12th Five-Year Plan for the National Economic and Social Development of the Xinjiang Uygur Autonomous Region divides the Tianshan Mountain Northern Slope Economic Belt into six major economic zones. They are the Urumqi-Changji Economic Zone (the Wu-Chang Economic Zone), the Turpan-Kumul Economic Zone (the Tu-Ha Economic Zone), the Shihezi-ManasShawan Economic Zone (the Shi-Ma-Sha Economic Zone), the Kuytun-Karamay-Wusu Economic Zone (the Kui-Ke-Wu Economic Zone), the Bortala-Jinghe-Alashankou Economic Zone (the Bo-Jing-A Economic Zone), the Gulja-Korgas-Qapqel Econom- ic Zone (the Yi-Huo-Cha Economic Zone). The study will accordingly conduct assessment of the environmental performance of each economic zone. The 12th Five-Year Plan for National Economic and Social Development of Xinjiang Uygur Autonomous Region also defines the direction of industrial development in each economic zone, as shown in Table 1.

The gross output values of the six major economic zones from 2011-2014 were as shown in Fig. 2. Except for the BoJing-A Economic Zone, the output of which declined slightly as a result of the drop in the city's economic activities for 2014, other economic zones have been witnessing an annual growth tendency in the gross output value.

In 2014, the total industrial output values of the $\mathrm{Wu}-\mathrm{Chang}$ and $\mathrm{Kui}-\mathrm{Ke}-\mathrm{Wu}$ economic zones, boasted the largest shares in the gross industrial output values of the Tianshan Mountain Northern Slope Economic Belt at $48 \%$ and $39 \%$ respectively, and were followed by the Tu-Ha (8\%), Yi-Huo-Cha (2\%), ShiMa-Sha (2\%), and Bo-Jing-A economic zones (1\%).

\section{Evaluation of Environmental Performance}

ISO14031 [17] defines environmental performance as "measurable results of an organization's management of its environmental factors." Methods of environmental performance evaluation are usually based on eco-efficiency analysis, data envelopment analysis, and so on. Considering the coverage and

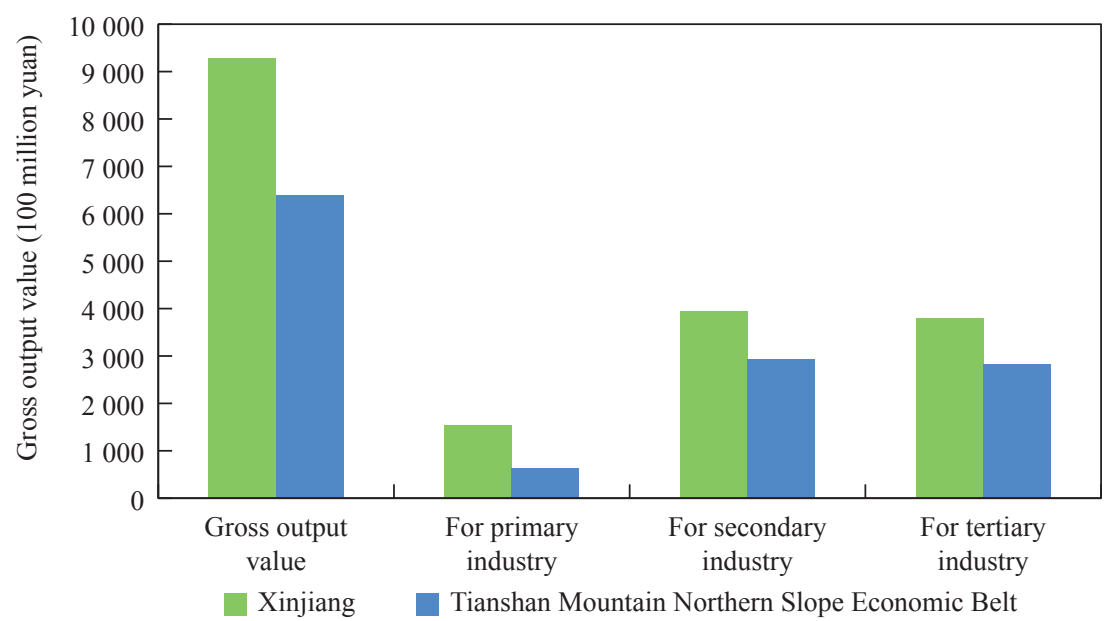

Fig. 1. Economic proportion of the Tianshan Mountain Northern Slope Economic Belt to Xinjiang in 2014.

Table 1. Six major economic zones and leading industries of the Tianshan Mountain Northern Slope Economic Belt.

\begin{tabular}{lcccc}
\hline Economic zone & Petrochemistry & Metallurgy & Food and beverage & Textile and clothing \\
\hline Kui-Ke-Wu & $\bullet$ & - & - & - \\
Tu-Ha & $\bullet$ & $\bullet$ & - & - \\
Wu-Chang & $\bullet$ & - & $\bullet$ & - \\
Bo-Jing-A & - & - & $\bullet$ & $\bullet$ \\
Shi-Ma-Sha & - & - & $\bullet$ \\
Yi-Huo-Cha & - & - & - \\
\hline
\end{tabular}




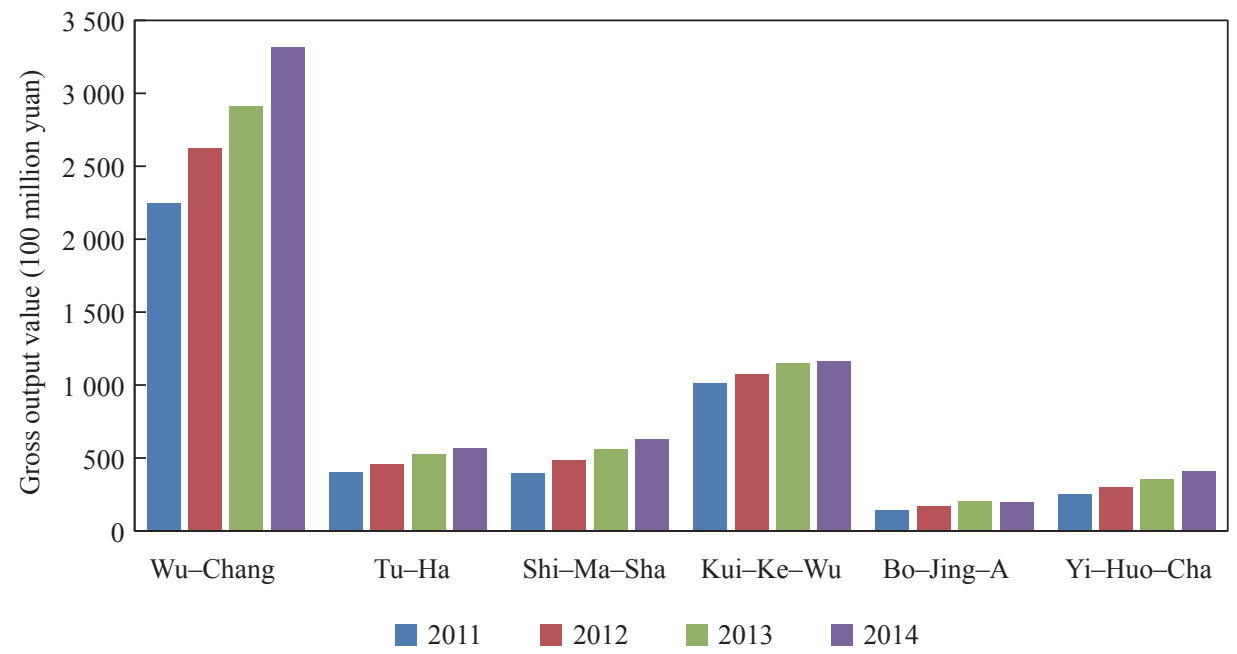

Fig. 2. Gross output values of each economic zone in the Tianshan Mountain Northern Slope Economic Belt from 2011-2014.

maneuverability of data collection in this study, the pollutant discharge intensity has been selected as the measure to evaluate the regional and industrial environmental performance.

Based on the two dimensions of region (six major economic zones) and industry (five leading industries), the pollutant discharge per unit of economic output (gross industrial output value, industrial added value), i.e., pollutant discharge intensity is selected to evaluate the environmental performance of each economic zone in the Tianshan Mountain Northern Slope Economic Belt, and is compared with the average discharge intensities of the whole country and Xinjiang. The lower the discharge intensity, the better the environmental performance. The formula for calculating the pollutant discharge intensity is as follows:

Pollutant discharge intensity $=$

Pollutant discharge

Gross industrial output value of the sector

The environmental performance evaluation based on pollutant discharge intensity can link the environment with the economy and characterize the level of green development of regional industry. A high discharge intensity indicates that the environmental performance is poor. So, to improve the level of green industrial development, the level of pollution prevention and control must be improved through structural adjustment and process optimization and by bringing down pollutant discharge while maintaining economic development. A low discharge intensity means that the environmental performance is good and that the level of industrial green development is high.

\subsection{Analysis of Discharge Intensity of Water pollutants}

The discharges of major pollutants (chemical oxygen demand, ammonia nitrogen) from wastewater in China and Xinjiang in 2014 have been compared in Table 2.

Level of water pollutant discharge in Xinjiang is about 5 times higher than the national average level of water pollutant discharge. Hence, the generally high discharge intensity of main pollutants in the wastewater of the Tianshan Mountain Northern Slope Economic Belt is a common problem, not only because of the industrial structure, but also due to the relatively extensive development mode.

\subsubsection{Chemical oxygen demand}

The two economic zones with the highest discharge of Chemical Oxygen Demand (COD) in the Tianshan Mountain Northern Slope Economic Belt are the Wu-Chang (32\%) and Shi-MaSha economic zones (32\%), followed by the Bo-Jing-A (20\%) and Kui-Ke-Wu economic zones (12\%), and then by the Tu-Ha

Table 2. Comparison of discharge of main pollutants in wastewater between China and Xinjiang.

\begin{tabular}{lcc}
\hline Pollutant discharge & China \\
\hline Chemical oxygen demand discharge from industrial source $\left(\times 10^{4} \mathrm{t}\right)$ & 311.3 \\
Ammonia-nitrogen discharge from industrial source $\left(\times 10^{4} \mathrm{t}\right)$ & 23.2 \\
Gross industrial output value (100 million yuan) & 1092198 \\
Chemical oxygen demand discharge intensity (kg/ten thousand yuan) & 0.285 \\
Ammonia nitrogen discharge intensity (kg/ten thousand yuan) & 0.021 & 1.573 \\
\hline
\end{tabular}


(2\%) and Yi-Huo-Cha economic zones (2\%). The comparison of the discharge intensity of COD in each economic zone is shown in Fig. 3.

The discharge intensities of COD in the Bo-Jing-A and ShiMa-Sha economic zones $(17.89 \mathrm{~kg} /$ ten thousand yuan, $9.85 \mathrm{~kg} /$ ten thousand yuan) are much higher than that in other economic zones, and are also higher than the average level in Xinjiang and across the country. The main reason is that the wastewater discharge of food and beverage and petrochemical enterprises of the region is large and intense. But from the previous analysis, we know that the petrochemical industry is not a leading industry in those regions; therefore, it should be phased out in future. The ratio of the COD discharge and the discharge intensity are compared with the average level of the Tianshan Mountain Northern Slope Economic Belt as shown in Table 3.

Industry ratio refers to the proportion of the pollutant discharge of leading industries to the gross pollutant discharge of the economic zone; intensity comparison refers to the specific value of pollutant discharge intensity of the industry of the economic zone to that of the industry of the Tianshan Mountain
Northern Slope Economic Belt; numbers in italics indicate that they are not leading industries of this economic zone (same hereunder).

This study focuses on identifying two types of industries. The first type is the "non-dominant, high-intensity" industry. It is not the leading industry in the economic zone, but has a high pollutant discharge intensity in the economic zone, for example, the petrochemical industry in the Shi-Ma-Sha Economic Planning Area and the Bo-Jing-A Economic Zone and the food and beverage industry in the Kui- $\mathrm{Ke}-\mathrm{Wu}$ Economic Zone. Such industries should be phased out in an orderly manner during future development. The second type is the "dominant, low-intensity" industry. It is a leading industry and its discharge intensity in the economic zone is lower than the average level of the Tianshan Mountain Northern Slope Economic Belt, such as the petrochemical industry in the Kui-Ke-Wu Economic Zone and the petrochemical industry and the coal and energy supply industry in the Tu-Ha Economic Zone. Development of such industries in the near future should be a priority; efforts have to be poured in to promote and popularize advanced technology and

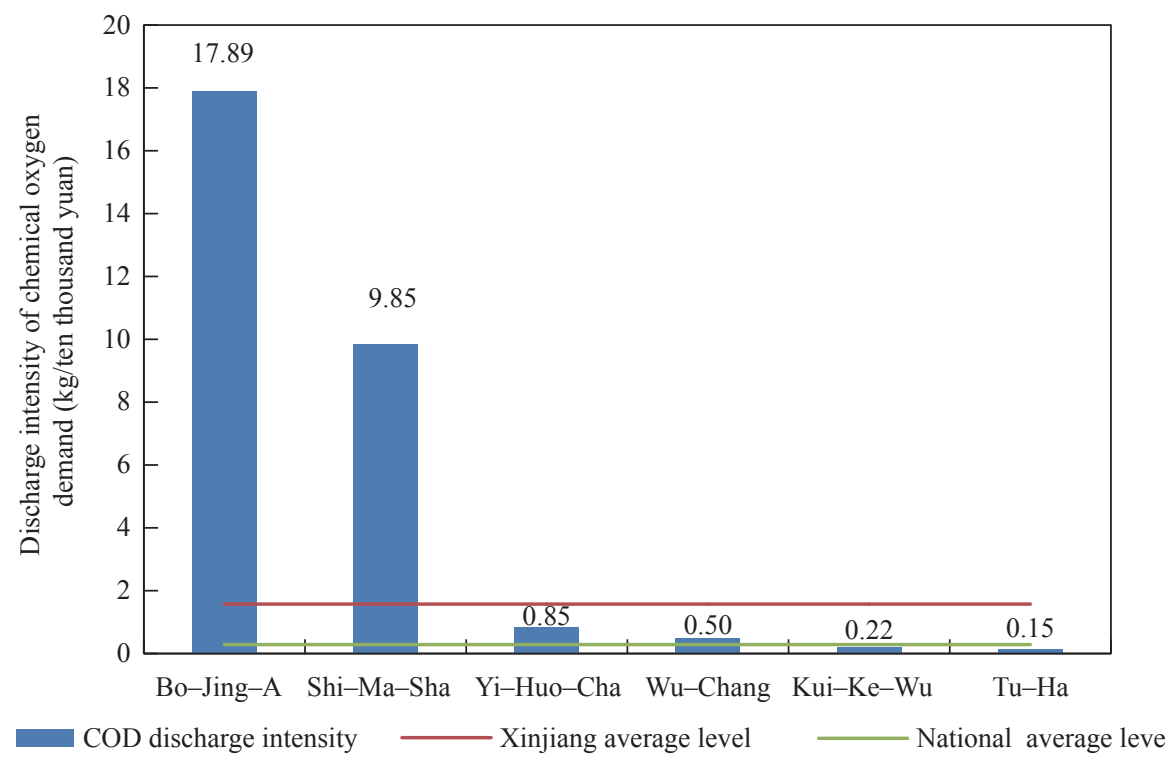

Fig. 3. Comparison of the discharge intensity of chemical oxygen demand in the 6 major economic zones.

Table 3. Comparison of discharge ratio and intensity of chemical oxygen demand.

\begin{tabular}{|c|c|c|c|c|c|c|c|c|c|c|c|c|}
\hline \multirow[b]{2}{*}{ Industry } & \multicolumn{2}{|c|}{ Wu-Chang } & \multicolumn{2}{|c|}{ Bo-Jing-A } & \multicolumn{2}{|c|}{ Shi-Ma-Sha } & \multicolumn{2}{|c|}{ Kui-Ke-Wu } & \multicolumn{2}{|c|}{ Yi-Huo-Cha } & \multicolumn{2}{|c|}{$\mathrm{Tu}-\mathrm{Ha}$} \\
\hline & $\begin{array}{l}\text { Industry } \\
\text { ratio }\end{array}$ & $\begin{array}{l}\text { intensity } \\
\text { comparison }\end{array}$ & $\begin{array}{l}\text { Industry } \\
\text { ratio }\end{array}$ & $\begin{array}{c}\text { intensity } \\
\text { comparison }\end{array}$ & $\begin{array}{l}\text { Industry } \\
\text { ratio }\end{array}$ & $\begin{array}{l}\text { intensity } \\
\text { comparison }\end{array}$ & $\begin{array}{l}\text { Industry } \\
\text { ratio }\end{array}$ & $\begin{array}{l}\text { intensity } \\
\text { comparison }\end{array}$ & $\begin{array}{l}\text { Industry } \\
\text { ratio }\end{array}$ & $\begin{array}{l}\text { intensity } \\
\text { comparison }\end{array}$ & $\begin{array}{l}\text { Industry } \\
\text { ratio }\end{array}$ & $\begin{array}{l}\text { intensity } \\
\text { comparison }\end{array}$ \\
\hline $\begin{array}{l}\text { Food and } \\
\text { beverage }\end{array}$ & $11 \%$ & 0.21 & $75 \%$ & 18.73 & $6 \%$ & 1.33 & $37 \%$ & 2.76 & $18 \%$ & 0.24 & $11 \%$ & 0.26 \\
\hline Metallurgy & $7 \%$ & 0.83 & - & - & - & - & - & - & - & - & $59 \%$ & 2.31 \\
\hline $\begin{array}{l}\text { Textile and } \\
\text { clothing }\end{array}$ & $1 \%$ & 3.55 & - & - & - & - & - & - & - & - & - & - \\
\hline $\begin{array}{l}\text { Coal and } \\
\text { energy }\end{array}$ & $5 \%$ & 1.06 & - & - & - & - & $3 \%$ & 1.52 & $4 \%$ & 0.69 & $14 \%$ & 0.62 \\
\hline
\end{tabular}


management concepts in these industries. They can then leading examples of industrial green development.

\subsubsection{Ammonia nitrogen}

The Wu-Chang Economic Zone shows a trend of monopoly in ammonia nitrogen discharge since it accounts for $87 \%$ of the discharge from the Tianshan Mountain Northern Slope Economic Belt, followed by the Shi-Ma-Sha Economic Zone $(6 \%)$, and so on. The ammonia nitrogen discharge intensity from four major economic zones, namely, Bo-Jing-A, Shi-Ma-Sha, $\mathrm{Wu}-\mathrm{Chang}$, and $\mathrm{Yi}-\mathrm{Huo}-\mathrm{Cha}$ are much higher than the national average, while the Kui-Ke-Wu and $\mathrm{Tu}-\mathrm{Ha}$ Economic Zones are lower than the national average level, as shown in Fig. 4.

The ammonia-nitrogen discharge of the two petrochemical industries of the Bo-Jing-A Economic Zone accounts for $56 \%$ of the gross discharge in this economic zone. Therefore, from the perspective of reduction of ammonia-nitrogen discharge, the BoJing-A Economic Zone shall take into consideration the orderly phasing out of the petrochemical industry. The comparison of ammonia-nitrogen discharge ratio and intensity with the average level of the industries in the Tianshan Mountain Northern Slope Economic Belt is shown in Table 4.
From the point of view of ammonia-nitrogen discharge, the industries that belong to the "non-dominant, high-intensity" industry group are the petrochemical industries in the Bo-JingA and Shi-Ma-Sha Economic Zones and the food and beverage and the coal and energy supply industries in the Kui-Ke-Wu Economic Zone; they should all be phased out. The control of ammonia nitrogen pollution in the Kui- $\mathrm{Ke}-\mathrm{Wu}$ and $\mathrm{Tu}-\mathrm{Ha}$ Economic Zones is quite proficient for the petrochemical industry (87\%), a key industry producing ammonia-nitrogen discharge. So, it should be developed first, using high-level technology and management, and then popularized.

\subsection{Discharge Intensity Analysis of Atmospheric Pollutants}

Discharge of major pollutants (sulfur dioxide, nitrogen oxide) from the nation and Xinjiang in 2014 have been compared as shown in Table 5.

The discharge intensity of atmospheric pollutants in Xinjiang is three times higher than that at the national level, similar to the discharge intensity of water pollutants. The dominant industrial structure in Xinjiang dictates that the intensity of atmospheric pollutants must be kept at a high level.

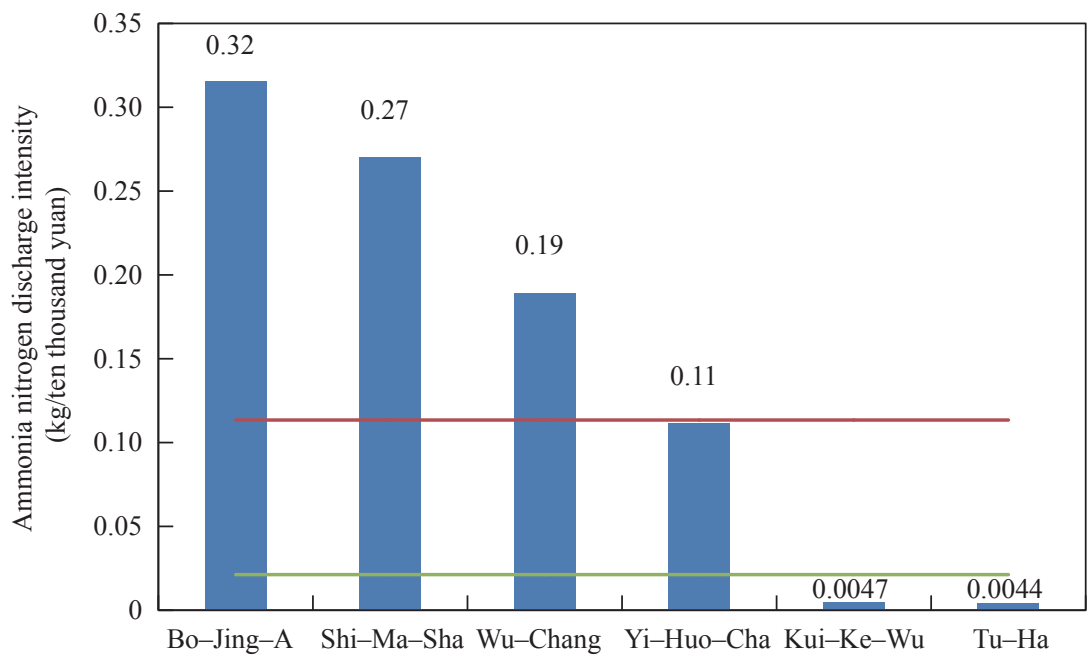

Ammonia nitrogendischarge intensity

Xinjiang average level

- National average leve

Fig. 4. Comparison of ammonia nitrogen discharge intensity in 6 major economic zones.

Table 4. Comparison of ammonia-nitrogen discharge ratio and intensity.

\begin{tabular}{|c|c|c|c|c|c|c|c|c|c|c|c|c|}
\hline \multirow[b]{2}{*}{ Industry } & \multicolumn{2}{|c|}{ Wu-Chang } & \multicolumn{2}{|c|}{ Bo-Jing-A } & \multicolumn{2}{|c|}{ Shi-Ma-Sha } & \multicolumn{2}{|c|}{ Kui-Ke-Wu } & \multicolumn{2}{|c|}{ Yi-Huo-Cha } & \multicolumn{2}{|c|}{$\mathrm{Tu}-\mathrm{Ha}$} \\
\hline & $\begin{array}{l}\text { Industry } \\
\text { ratio }\end{array}$ & $\begin{array}{l}\text { intensity } \\
\text { comparison }\end{array}$ & $\begin{array}{l}\text { Industry } \\
\text { ratio }\end{array}$ & $\begin{array}{l}\text { intensity } \\
\text { comparison }\end{array}$ & $\begin{array}{l}\text { Industry } \\
\text { ratio }\end{array}$ & $\begin{array}{l}\text { intensity } \\
\text { comparison }\end{array}$ & $\begin{array}{l}\text { Industry } \\
\text { ratio }\end{array}$ & $\begin{array}{l}\text { intensity } \\
\text { comparison }\end{array}$ & $\begin{array}{c}\text { Industry } \\
\text { ratio }\end{array}$ & $\begin{array}{l}\text { intensity } \\
\text { comparison }\end{array}$ & $\begin{array}{l}\text { Industry } \\
\text { ratio }\end{array}$ & $\begin{array}{l}\text { intensity } \\
\text { comparison }\end{array}$ \\
\hline Petrochemistry & $93 \%$ & 3.43 & $56 \%$ & 21.28 & $79 \%$ & 2.74 & $27 \%$ & 0.01 & - & - & $28 \%$ & 0.02 \\
\hline $\begin{array}{l}\text { Food and } \\
\text { beverage }\end{array}$ & $2 \%$ & 0.60 & $40 \%$ & 5.93 & $15 \%$ & 3.31 & $31 \%$ & 1.65 & $18 \%$ & 1.02 & $44 \%$ & 0.97 \\
\hline Metallurgy & $2 \%$ & 1.16 & - & - & - & - & $1 \%$ & 1.65 & - & - & $6 \%$ & 0.10 \\
\hline $\begin{array}{l}\text { Textile and } \\
\text { clothing }\end{array}$ & - & - & $3 \%$ & 1.04 & $1 \%$ & 4.76 & $2 \%$ & 0.50 & $1 \%$ & 6.21 & - & - \\
\hline $\begin{array}{l}\text { Coal and } \\
\text { energy }\end{array}$ & $1 \%$ & 0.75 & - & - & $1 \%$ & 0.70 & $30 \%$ & 4.32 & $6 \%$ & 1.47 & $9 \%$ & 0.14 \\
\hline
\end{tabular}




\subsubsection{Sulfur dioxide}

The sulfur dioxide discharge in the three economic zones of Wu-Chang, Kui-Ke-Wu and Tu-Ha accounted for $57 \%, 16 \%$, and $14 \%$ respectively of the gross sulfur dioxide discharge from the Tianshan Mountain Northern Slope Economic Belt, and totaled to $87 \%$. The three economic zones are also areas with low sulfur dioxide discharge intensity. As shown in Fig. 5, the Tianshan Mountain Northern Slope Economic Belt has done well in sulfur dioxide discharge control.

From the dimension of industry, the Yi-Huo-Cha Economic Zone has a large and intense discharge for its coal and energy supply industry, which results in relatively severe air pollution in the economic zone. The Kui-Ke-Wu Economic Zone has the lowest sulfur dioxide discharge intensity but a high concentration (discharge from top ten large-discharge enterprises accounts for $97.9 \%$ discharge in the region).

The ratio of sulfur dioxide discharge and the discharge intensity are compared with the industrial average level of the Tianshan Mountain Northern Slope Economic Belt, as shown in Table 6.

From the perspective of sulfur dioxide discharge, the industry that belongs to the "non-dominant, high-intensity" industry is the

Table 5. Comparison of discharge of major pollutants in exhaust gas between China and Xinjiang.

\begin{tabular}{lcc}
\hline Pollutant discharge & China & Xinjiang \\
\hline Sulfur dioxide discharge from industrial source $\left(\times 10^{4} \mathrm{t}\right)$ & 1740.4 & 55.28 \\
Nitrogen oxide discharge from industrial source $\left(\times 10^{4} \mathrm{t}\right)$ & 1404.8 & 40 \\
Gross industrial output value $(100$ million yuan) & 1092198 & 9431.76 \\
Sulfur dioxide discharge intensity $(\mathrm{kg} /$ ten thousand yuan) & 1.593 & 5.861 \\
Nitrogen oxide discharge intensity (kg/ten thousand yuan) & 1.286 & 4.241 \\
\hline
\end{tabular}

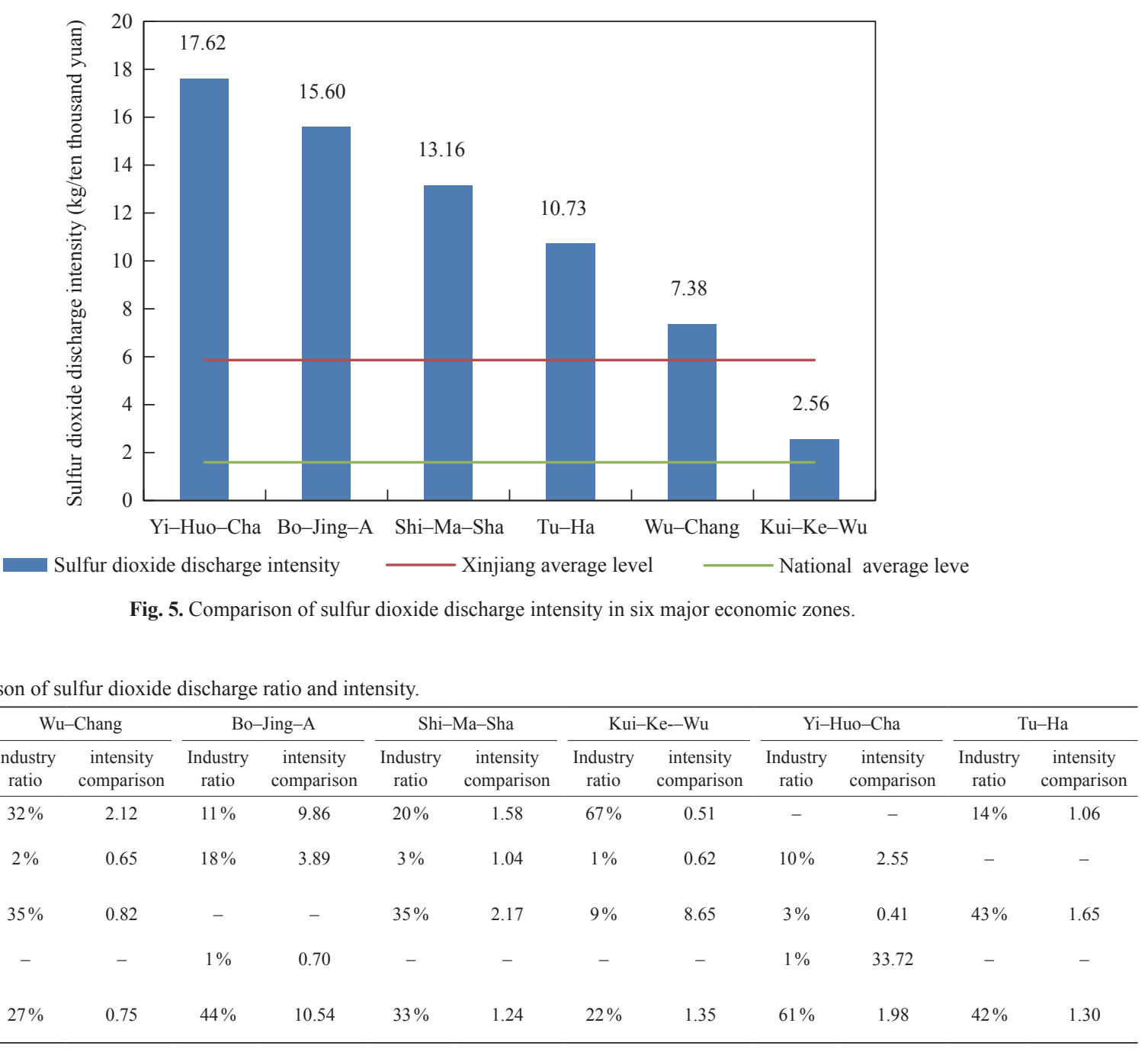


petrochemical industry of the Shi-Ma-Sha Economic Zone and the metallurgy and the coal and energy supply industries of the Kui-Ke-Wu economic region, both of which should be phased out.

\subsubsection{Nitrogen oxide}

The discharge of nitrogen oxides in the $\mathrm{Wu}-\mathrm{Chang}$ Economic Zone accounts for $60 \% \mathrm{t}$ of the total discharge of the Tianshan Mountain Northern Slope Economic Belt, followed by $\mathrm{Tu}-\mathrm{Ha}$ (13\%), Kui-ke-Wu (12\%) and so on. The intensity of nitrogen oxide discharge in each economic zone is similar to the intensity of sulfur dioxide discharge. Besides the Kui-Ke-Wu Economic Zone (1.92 kg/ten thousand yuan), the remaining five economic zones have a higher discharge intensity of nitrogen oxides than the national and Xinjiang average levels, as shown in Fig. 6.

From the perspective of industry, the petrochemical industry and the coal and energy supply industry in the Shi-Ma-Sha Economic Zone, have a large and intense discharge of nitrogen oxides, which is responsible for the high discharge intensity of the economic zone. Although the petrochemical industry is not the leading industry in this economic zone, the proportion of its industrial output value is as high as $44.7 \%$. Therefore, for future industrial development, it is suggested that the overall technical equipment level of the industry be raised and the discharge intensity of nitrogen oxides be reduced.

The comparison of nitrogen oxide discharge ratio and intensity with the industry average level in the Tianshan Mountain Northern Slope Economic Belt is shown in Table 7.

The "non-dominant, high-intensity" industries emitting nitrogen oxide include the petrochemical industry in the BoJing-A Economic Zone, the coal and energy supply industry and the metallurgical industry in the Kui-Ke-Wu Economic Zone, the petrochemical industry in the Bo-Jing-A Economic Zone, and the metallurgy industry in the Kui-Ke-Wu Economic Zone, in particular, all of which should be phased out as soon as possible.

\section{Recommendations on the green development strategy}

The results of the environmental performance evaluation by integrating industrial and regional dimensions, showed that the

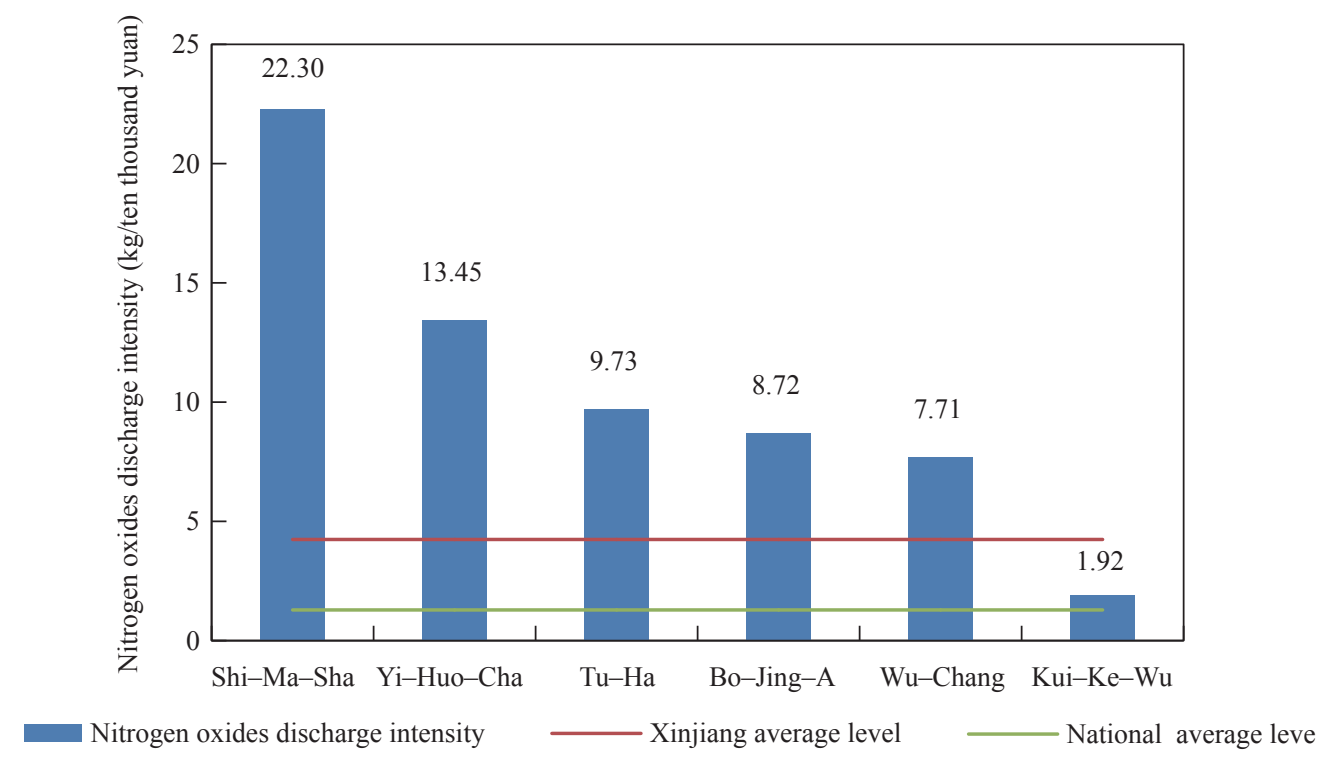

Fig. 6. Comparison of nitrogen oxide discharge intensity in six major economic zones.

Table 7. Comparison of discharge ratio and intensity of nitrogen oxides.

\begin{tabular}{|c|c|c|c|c|c|c|c|c|c|c|c|c|}
\hline \multirow[b]{2}{*}{ Industry } & \multicolumn{2}{|c|}{ Wu-Chang } & \multicolumn{2}{|c|}{ Bo-Jing-A } & \multicolumn{2}{|c|}{ Shi-Ma-Sha } & \multicolumn{2}{|c|}{ Kui-Ke-Wu } & \multicolumn{2}{|c|}{ Yi-Huo-Cha } & \multicolumn{2}{|c|}{$\mathrm{Tu}-\mathrm{Ha}$} \\
\hline & $\begin{array}{c}\text { Industry } \\
\text { ratio }\end{array}$ & $\begin{array}{l}\text { intensity } \\
\text { comparison }\end{array}$ & $\begin{array}{l}\text { Industry } \\
\text { ratio }\end{array}$ & $\begin{array}{l}\text { intensity } \\
\text { comparison }\end{array}$ & $\begin{array}{c}\text { Industry } \\
\text { ratio }\end{array}$ & $\begin{array}{l}\text { intensity } \\
\text { comparison }\end{array}$ & $\begin{array}{l}\text { Industry } \\
\text { ratio }\end{array}$ & $\begin{array}{l}\text { intensity } \\
\text { comparison }\end{array}$ & $\begin{array}{l}\text { Industry } \\
\text { ratio }\end{array}$ & $\begin{array}{l}\text { intensity } \\
\text { comparison }\end{array}$ & $\begin{array}{l}\text { Industry } \\
\text { ratio }\end{array}$ & $\begin{array}{l}\text { intensity } \\
\text { comparison }\end{array}$ \\
\hline Petrochemistry & $31 \%$ & 2.52 & $10 \%$ & 6.00 & $6 \%$ & 0.93 & $64 \%$ & 0.44 & - & - & $3 \%$ & 0.26 \\
\hline $\begin{array}{l}\text { Food and } \\
\text { beverage }\end{array}$ & $1 \%$ & 0.57 & $8 \%$ & 2.47 & $1 \%$ & 0.72 & - & - & $3 \%$ & 1.64 & - & - \\
\hline Metallurgy & $23 \%$ & 0.95 & - & - & $23 \%$ & 3.92 & $8 \%$ & 9.43 & $2 \%$ & 0.37 & $19 \%$ & 1.10 \\
\hline $\begin{array}{l}\text { Textile and } \\
\text { clothing }\end{array}$ & - & - & - & - & - & - & - & - & - & - & - & - \\
\hline Coal and energy & $39 \%$ & 0.79 & $17 \%$ & 1.65 & $62 \%$ & 2.85 & $24 \%$ & 0.78 & $58 \%$ & 1.03 & $74 \%$ & 1.48 \\
\hline
\end{tabular}




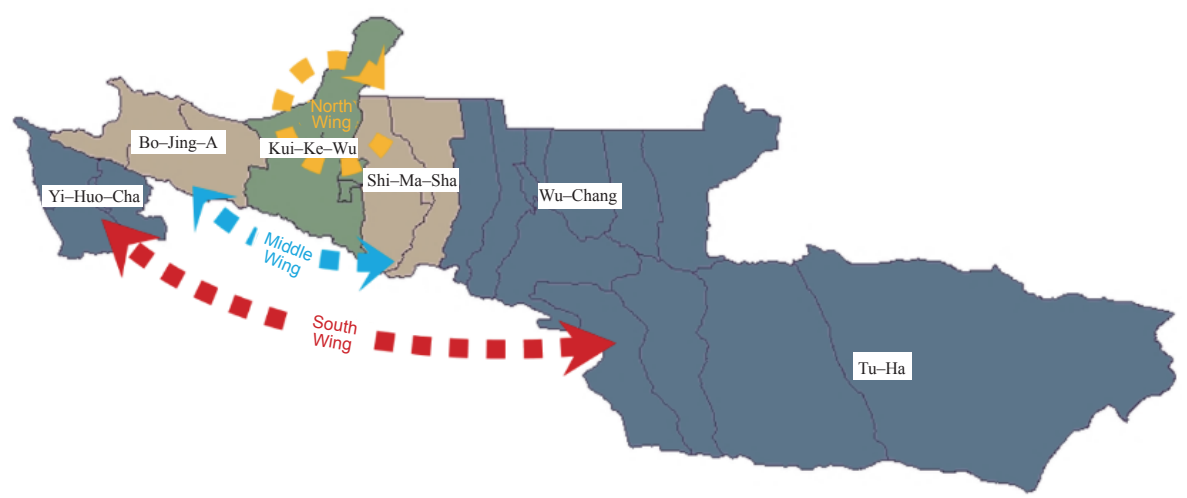

Fig. 7. Division of the south, middle and north wing of the Tianshan Mountain Northern Slope Economic Belt.

environmental performance of the north wing (Kui-Ke-Wu) was the best, followed by the south wing (Yi-Huo-Cha, Wu-Chang, $\mathrm{Tu}-\mathrm{Ha}$ ) and the middle wing (Shi-Ma-Sha, Bo-Jing-A). For this reason, the paper proposes recommendations of "one overall and three wings" strategy to promote the green development of industries in the Tianshan Mountain Northern Slope Economic Belt, with the division of "three wings" as shown in Fig. 7.

\subsection{Overall: Comprehensively promote pollution prevention and control in the Tianshan Mountain Northern Slope Economic Belt and improve the level of green development of industries}

The Tianshan Mountain Northern Slope Economic Belt and the whole of Xinjiang still have a big gap in terms of the prevention and control of industrial pollution with the national average level. It is suggested that the six economic zones should constantly adjust their industrial structure and optimize their new industrial layout during the future development processes, strengthen measures for environmental access, prohibit the addition of backward production capacity, encourage the development of high-quality production capacity, reduce the intensity of pollutant emissions, improve the quality of development, and promote green development in an all-round manner.

\subsection{Middle Wing: Accelerate the elimination of backward production capacity and rigorously implement the environment access for the industries}

Step up efforts in the elimination of the petrochemical industry and the coal and energy supply industry in the Bo-Jing-A economic zone and the petrochemical industry in the Shi-MaSha economic zone. It is necessary to control the generation of pollutants from the source and to improve terminal treatment facilities and treatment efficiency. In order to reduce the emission intensity of pollutants and improve the emission standards, it is necessary to move forward with the discharge reduction work in an all-round manner in accordance with the national standards.
4.3 South Wing: Give equal emphasis on source reduction and process control and promote green development of industries

Strengthen the prevention and control of ammonia-nitrogen and air pollution in the petrochemical industry of the $\mathrm{Wu}$ Chang Economic Zone. Strengthen the management of pollution discharge of enterprises, impose punitive charges on enterprises that fail to meet the standards of discharge, and collect environmental treatment deposits for environmental improvement from new and expanded enterprises; actively carry out clean production, raise the requirements for meeting the first-class index in clean production standard, pay equal attention to source reduction and process control, and realize the goal of green development of industry and region.

\subsection{North Wing: Focus on innovate environmental} management and promote the sustainable green development of industries

Promote the petrochemical industry to cluster, scale up, and embrace green development, strengthen the efforts in reduction of water pollutant discharge in the food industry and the coal and energy supply industry, promote reduction of atmospheric pollutants discharge in the metallurgy industry; strengthen the regional fine environmental management, make bold attempts such as introducing the green supply chain, environmental leadership, environmental Internet of things, third party environmental services, emissions trading, and other innovative environmental management measures to promote industrial green sustainable development.

\section{References}

[1] Gu H X, Luo J. Development strategy in Tianshan Mountain Northern Slope Economic Belt [J]. Journal of Xinjiang University of Finance \& Economics, 2000 (6): 2-6. Chinese.

[2] Wang Q M. Some problems about development of the agricultural 
market in Kumul [J]. Seek Truth From Facts, 2000 (6): 67-68. Chinese.

[3] Tursun H, Ye W H, Meng X Y, et al. Great exploitation of the west and the basic thoughts of the great development strategy of Xinjiang [J]. Arid Land Geography, 2000, 23(3): 193-198. Chinese.

[4] Li X Q, Wang Y J. A synthetical evaluation of ecological environmental in Northern Slope Economic Zone of Tian Mountains based on RS and GIS techniques [J]. Environmental Protection of Xinjiang, 2003, 25(2): 1-4. Chinese.

[5] Tang H, Yang D G, Sun C, et al. Synthetical assessment of ecoenvironment in the Economic Belt on the Northern Slop of the Tianshan Mountains based on AHP [J]. Arid Land Geography, 2010, 33(4): 659-665. Chinese.

[6] Zhao X H, Yao J, Ma J. The gray analysis of water sources carrying capacity evolvement in Xinjiang based on GINI coefficient: A case study of Tianshan North Slope Economic Zone [J]. Water Saving Irrigation, 2016 (5): 85-88. Chinese.

[7] Zhang P P. Urban comprehensive carrying capacity evaluation of Economic Belt of Tianshan North-Slope (Master's thesis) [D]. Shihezi: Shihezi University, 2015. Chinese.

[8] Ha S C, Kasimu A. Coordination evaluation between urban human settlement environment quality and urbanization development of the Economic Belt on the North Slope of Tianshan [J]. Research of Soil and Water Conservation, 2016, 23(1): 303-308. Chinese.

[9] Li D. The research on new urbanization of the Tianshan Northern Slope Economic Belt (Master's thesis) [D]. Urumqi: Xinjiang
University, 2016. Chinese.

[10] Yu M, Zhang Q, Guo L M. Development strategy on green food industry in Xinjiang $[\mathrm{J}]$. Xinjiang Agricultural Sciences, 2003 (S2): 38-40. Chinese.

[11] Sun X A, Liu Q, Jia J S. The thinking about development of the green industry in Xinjiang cement industry [J]. China Building Materials, 2000 (12): 59-61. Chinese.

[12] Kushwaha1 G S, Sharma N K. Green initiatives: A step towards sustainable development and firm's performance in the automobile industry [J]. Journal of Cleaner Production, 2016, 121: 116-129.

[13] Lei K, Pan H Y, Lin C Y. A landscape approach towards ecological restoration and sustainable development of mining areas $[\mathrm{J}]$. Ecological Engineering, 2016, 90: 320-325.

[14] Dai H C, Xie X X, Xie Y, et al. Green growth: The economic impacts of large-scale renewable energy development in China [J]. Applied Energy, 2016, 162: 435-449.

[15] Foo K Y. A vision on the opportunities, policies and coping strategies for the energy security and green energy development in Malaysia [J]. Renewable and Sustainable Energy Reviews, 2015, 51: 1477-1498.

[16] Statistic Bureau of Xinjiang Uygur Autonomous Region. Xinjiang statistical yearbook 2015 [M]. Beijing: China Statistics Press, 2015. Chinese.

[17] International Organization for Standardization Technical. ISO 14031:2013 Environmental management-environmental performance evaluation-guidelines [S]. Geneva: 2013. 